\title{
Photokeratoconjunctivitis Symptoms among Informal Welding Operators in North Samarinda, Indonesia
}

\author{
Iwan Muhamad Ramdan, Siti Badriatul Mursyidah, Siti Jubaedah \\ Faculty of Public Health, Mulawarman University, Samarinda
}

\begin{abstract}
Informal sector has been contributing to the national economy but occupational health and safety practices in the sector has not been satisfactory. One of the informal sector which are found in North Samarinda is informal welding workshop, with dominant hazards is exposure to ultraviolet rays that can cause photokeratoconjunctivitis. The Objective of this study was to investigate the symptoms of photokeratoconjunctivitis and related factors among informal welding operator in North Samarinda. A cross-sectional study was conducted on 40 respondents. Research was conducted in March until November 2016. Data collection using ultraviolet detector meter, clamps meter, and questionnaire. Data analysis using chi-square, Pearson's correlation product moment and multiple linear regression. Fifty percents of respondents have photokeratoconjunctivitis symptoms. Personal protective equipment (PPE) $(\mathrm{p}=0.004)$, UV exposure duration (o.056), knowledge of health and safety $(\mathrm{p}=0.055)$ and number of working days $(\mathrm{p}=0.001)$ were associated with photokeratoconjunctivitis symptoms. Work location $(\mathrm{p}=0.244)$, level of education $(\mathrm{p}=0.680)$, age $(0.167)$, intensity of UV radiation $(\mathrm{p}=0.206)$ and strength of welding current $(\mathrm{p}=0.085)$ were not related to photokeratoconjunctivitis symptoms. In conclusions, photokeratoconjunctivitis symptoms is influenced by the use of PPE, UV exposure duration, knowledge of health and safety, and number of working days. The most influential factor to the appearance of photokeratoconjunctivitis $(\beta=0.32)$ is duration of UV exposure.
\end{abstract}

Key words: Knowledge, OHS, photokeratoconjunctivitis, PPE, UV exposure, working days

\section{Gejala Photokeratoconjunctivitis pada Pekerja Las Informal di Samarinda Utara, Indonesia}

\begin{abstract}
Abstrak
Sektor informal telah berkontribusi terhadap perekonomian nasional, namun praktik kesehatan dan keselamatan kerja pada sektor ini masih belum memuaskan. Salah satu usaha sektor informal yang banyak dijumpai di Samarinda Utara adalah usaha pengelasan dengan potensi bahaya utama paparan sinar ultraviolet yang dapat menyebabkan photokeratoconjunctivitis. Penelitian ini bertujuan menginvestigasi kejadian photokeratoconjunctivitis dan faktor yang memengaruhinya pada operator las informal di Kelurahan Samarinda Utara. Penelitian crosssectional telah dilakukan terhadap 40 responden pada bulan Maret sampai November 2016. Pengumpulan data menggunakan UV detector meter, clamp meter, dan kuesioner. Analisis data menggunakan chi-square, Pearson's correlation product moment, dan multiple linear regression. Lima puluh persen responden mengalami gejala photokeratoconjunctivitis. Alat pelindung diri (APD) $(\mathrm{p}=0,004)$, durasi paparan UV $(0,056)$, pengetahuan tentang kesehatan dan keselamatan kerja $\left(\mathrm{K}_{3}\right)(\mathrm{p}=0,055)$, dan jumlah hari kerja $(\mathrm{p}=0,001)$ berhubungan signifikan dengan kejadian photokeratoconjunctivitis. Lokasi kerja $(\mathrm{p}=0,244)$, tingkat pendidikan $(\mathrm{p}=0,680)$, usia $(0,167)$, intensitas radiasi UV ( $\mathrm{p}=0,206)$, dan kuat arus las $(\mathrm{p}=0,085)$ tidak berhubungan dengan gejala photokeratoconjunctivitis. Simpulan, gejala photokeratoconjunctivitis dipengaruhi oleh penggunaan APD, durasi paparan UV, pengetahuan $\mathrm{K}_{3}$, dan jumlah hari kerja. Faktor yang paling dominan memengaruhi gejala photokeratoconjunctivitis adalah durasi paparan UV.
\end{abstract}

Kata kunci: APD, hari kerja, K3, paparan UV, pengetahuan, photokeratoconjunctivitis 


\section{Introduction}

Many studies have shown that the informal sector and informal employment continue to be a large, even growing, and essential component of the economies in developing countries. Workforces in the informal sector is estimated to employ more than $50 \%$ of nonagricultural employment and nearly $30 \%$ of nonagricultural gross domestic product (GDP) in Asia. In Indonesia, 70\% of the workforce was estimated to be engaged in informal employment. Badan Pusat Statistik (BPS) have estimated informal employment to be about $64 \%$ and the share of small enterprises (that seem to be mostly informal) to the GDP output to be roughly $38 \%$. Informal sector and informal employment statistics have not been regularly collected and have not been included in Indonesia's official labor force statistics. The informal sector contributes significantly to Indonesia's economy, particularly in terms of employment, by providing economic opportunities to those displaced from or who cannot be absorbed by the formal sector. ${ }^{1}$

Health and safety conditions among informal sector in Indonesia are alarmingly unsave. The conditions include lack of legal protection for nonpayment of wages, retrenchment without notices or compensations, unsatisfactory occupational health and safety conditions and an absence of social benefits such as pensions, sick pays and health insurance. Women, migrants, children and other vulnerable groups of workers who are excluded from other opportunities have little choice but to take informal low-quality jobs. ${ }^{2}$

One of the many informal sectors mostly found in Samarinda city is informal welding workshops. This workshops spread all over several villages, producing canopies, railings, home accessories, doors and metal windows, stores and many others. Preliminary study results showed welding skills acquired through informal learning from colleagues or family members; almost all smallscale workshop but its own; welding operator has been working for many years sedentary workshop or settled; the duration of the working day on average over 8 hours/day or more if it is a lot of consumers; workplace conditions there are outside and indoors; not all operators welded using personal protective equipment when working; knowledge of occupational health and safety is very low.

Potential hazard faced by the welding operators is eye injury. This is caused by an inflammatory reaction in the cornea and conjunctiva known as photokeratoconjunctivitis. The condition will lead to a swelling and loss of the superficial cells in the cornea and the conjunctiva. Within 24-48 hours, the pain decreases and the light sensitivity disappears. This condition is popularly referred to as "snowblindness" or "welders flash." This complaint is acute effects that occur within six hours after welding with a chief complaint eyes feel itchy, gritty eye sensation (foreign objects), watery eyes continuously, until the severe pain in the eye and photophobia (sensitivity to light). The primary causes of eye disorders come from ultraviolet rays generated during the welding process. Wave ultraviolet rays reach the cornea, lens and retina even nearly reached. ${ }^{3}$

Eye injuries are the most common conditions experienced by welding operators. According to International Labor Organization (ILO) ${ }^{4}$ welders may be injured by flying sparks and particles of hot metal, ultraviolet radiation, and metal fumes, which may seriously threaten the arc welders' health. Foreign bodies in the eyes are the most common type of injuries sustained by these welders. Most (85\%) in Northern Nigeria welding operator injured at work, $17 \%$ of whom are arc eye injuries/foreign bodies. ${ }^{5}$ Some of the effects of welding on health include photokeratitis or arc eye, metal fume fever, decrease in lung function, pneumoconiosis, asthma, photodermatitis and fertility abnormalities. ${ }^{6}$

Indonesia Basic Health Research done in 2013 explained that one of the causes of eye injury is occupational accidents due to exposure to sharp or blunt tools/machinery, falling objects, poisoning, radiation, burns and others. Eye injuries usually were unintentional. The proportion of patients with eye injuries in Indonesia on civil servants, self-employed, farmer or fisherman or labor was $0.7 \%$, whereas in East Kalimantan, the proportion of eye injuries was $0.8 \%$. This figure is the fourthhighest in Indonesia. ${ }^{7}$

The objective of this study was to investigate photokeratoconjunctivitis symptoms prevalences and related factors on informal welding operators in the North Samarinda region, Province of East Kalimantan, Indonesia.

\section{Methods}

This was a cross-sectional study on 40 informal welding operators in North Samarinda villages. Research was conducted in March until November 2016. The dependent variable in this study was photokeratoconjunctivitis symptom $(\mathrm{Y})$, while the 
independent variables were age $\left(\chi_{1}\right)$, the intensity of UV radiation $\left(\mathrm{X}_{2}\right)$, UV exposure duration $\left(\mathrm{X}_{3}\right)$, knowledge of occupational health and safety (OHS) $\left(x_{4}\right)$, the number of working days in a week $\left(\mathrm{X}_{5}\right)$, and strength of welding current $\left(\mathrm{X}_{6}\right)$. Other variables analyzed in this study are the relationship between the level of education, the use of personal protective equipment (PPE) and work location.

Ultraviolet detector meter was used to measure level of ultraviolet radiation, while welding current strength measured by clamps meter. Assessment of photokeratoconjunctivitis symptoms, duration of exposure, length of employment, use of personal protective equipments and welding locations were collected using valid questionnaires that has been tested prior to data collection. Complaints of photokeratoconjunctivitis symptoms consist of: gritty eyes, photophobia, itchy eyes, increased tears (lacrimation), eye pain, blurred visions, swollen eyelids and red eyes.

Statistical analysis used were chi square test and Pearson correlation product moment, while to analyze the most influential variable multiple logistic regression test was used, a p value $<0.05$ was considered statistically significant. All data were coded and analyzed using SPSS $₫$ ver 17 for Windows $®$.

Ethical clearance issued by Commission on Ethics of Public Health Research, Faculty of Public Health, Mulawarman University No. 01/ UN17.11/EC/III/2016.

\section{Results}

Demografic data of respondents and result of univariate analysis are presented in Table 1 . The majority of respondents were $\leq 30$ years old $(52.5 \%)$, high school graduates $(65 \%)$, with working period of more than five years and level of knowledge about health and safety at work is low (72.5\%). Fifty percents of welding operators complained of having photokeratoconjunctivitis. Most of the respondents were exposed to UV radiation below threshold limit value while only $35 \%$ of respondents exposed to UV radiation above threshold limit value. The majority of respondents were exposed to UV radiation in less

Table 1 Characteristic and Prevalence of Photokeratoconjunctivitis Symptomps of Informal Welding Operators in North Samarinda $(n=40)$

\begin{tabular}{lll}
\hline \multicolumn{1}{c}{ Characteristic } & & n (\%) \\
\hline Age (years) & $\leq 30$ & $21(53)$ \\
& $>30$ & $19(47.5)$ \\
Level of education & Primary school & $3(7)$ \\
& Junior high school & $11(28)$ \\
Working period (years) & Senior high school & $26(65)$ \\
& $\leq 5$ & $17(42)$ \\
Level of occupational health and safety knowledge & $>5$ & $23(58)$ \\
& High & $11(27)$ \\
Photokeratoconjunctivitis symptoms & Low & $29(73)$ \\
& Yes & $20(50)$ \\
Ultraviolet radiation & No & $20(50)$ \\
& Above TLV & $14(35)$ \\
Exposure of ultraviolet radiation per days & Below TLV & $26(65)$ \\
Number of working days per week & $\leq 4$ hours & $27(68)$ \\
& $\geq 4$ hours & $13(32)$ \\
Use of personal protective equipment & $1-3$ & $6(15)$ \\
& $4-7$ & $34(85)$ \\
Work location & Yes & $25(63)$ \\
Strong of welding curent & No & $15(37)$ \\
& Indoor & $4(10)$ \\
& Outdoor & $36(90)$ \\
& Strong & $10(25)$ \\
& Weak & $30(75)$ \\
\hline
\end{tabular}


Table 2 Chi-Square Test Results to Analyze the Relationship between the Use of PPE, Work Location and Level of Education with Photokeratoconjunctivitis Symptomps of Informal Welding Operator in North Samarinda $(n=40)$

\begin{tabular}{|c|c|c|c|c|c|c|c|}
\hline \multirow{2}{*}{ Variables } & & \multicolumn{3}{|c|}{ Used of PPE } & \multirow{2}{*}{$\mathbf{p}^{*}$} & \multicolumn{2}{|c|}{ Unadjusted OR } \\
\hline & & Yes & - & No & & & $95 \% \mathrm{CI}$ \\
\hline \multirow{2}{*}{$\begin{array}{l}\text { Symptom of } \\
\text { photokeratoconjunctivitis }\end{array}$} & Yes & 12 & & 8 & \multirow[t]{2}{*}{0.004} & \multirow{2}{*}{2.125} & \multirow{2}{*}{$1.205-3.748$} \\
\hline & No & 3 & & 7 & & & \\
\hline \multicolumn{8}{|c|}{ Work location } \\
\hline & & Outdoc & & Indoor & \multirow{3}{*}{0.244} & \multirow{3}{*}{0.900} & \\
\hline \multirow{4}{*}{$\begin{array}{l}\text { Symptom of } \\
\text { photokeratoconjunctivitis }\end{array}$} & Yes & o & & 20 & & & \multirow[t]{2}{*}{$0.788-1.042$} \\
\hline & No & 2 & & 18 & & & \\
\hline & & \multicolumn{3}{|c|}{ Level of education } & & & \\
\hline & & ES & JHS & SHS & \multirow{3}{*}{0.680} & \multirow{3}{*}{-} & \multirow{3}{*}{-} \\
\hline \multirow{2}{*}{$\begin{array}{l}\text { Symptom of } \\
\text { photokeratoconjunctivitis }\end{array}$} & Yes & 1 & 6 & 13 & & & \\
\hline & No & 2 & 4 & 14 & & & \\
\hline
\end{tabular}

${ }^{*}$ Calculated using $\chi^{2}$ at $\mathrm{df}=2$

$\mathrm{PPE}=$ personal protective equipment, ES=elementry school, JHS=junior high school, SHS=senior high school

than 4 hours per day, with numbers of working days per week of 4 to 6 working days (one working day $=8$ hours). Majority respondents work using personal protective equipments, working inside a room, and used weak welding currents $(<80$ amp).

Based on Table 4, it can be seen that overall, a fairly strong correlation between age, intensity of UV radiation, duration of UV exposure, knowledge health and safety, and the number of working days with photokeratoconjunctivitis $(\mathrm{R}=0.45)$, with a contribution of $20 \%\left(\mathrm{R}^{2}=0.20\right)$. Simultaneously, age $\left(\chi_{1}\right)$, intensity of $U V$ radiation $\left(\chi_{2}\right)$, duration of UV exposure $\left(\chi_{3}\right)$, knowledge of health and safety $\left(x_{f}\right)$, number of working days $\left(x_{5}\right)$, and strength of welding currents $\left(\chi_{6}\right)$ associated with the photokeratoconjunctivitis $(\mathrm{F}=1.096)$. However, partial $t$ test result showed there is no correlation between age $(\mathrm{p}=\mathrm{0.349})$, intensity of UV radiation $(p=0.158)$, knowledge strength $(p=0.206)$ with photokeratoconjunctivitis. Some variables that were partially related to photokeratoconjunctivitis were the duration of UV exposure $(p=0.055)$ and the number of working days $(\mathrm{p}=0.037)$. The regression model can be written as follows:

$$
\begin{aligned}
\mathrm{Y}= & \mathrm{a}+\mathrm{b}_{1} \cdot \mathrm{X}_{1}+\mathrm{b}_{2} \cdot \mathrm{X}_{2}+\mathrm{b}_{3} \cdot \mathrm{X}_{3}+\mathrm{b}_{4} \cdot \mathrm{X}_{4}+\mathrm{b}_{5} \cdot \mathrm{X}_{5}+\mathrm{b}_{6} \cdot \mathrm{X}_{6}+\mathrm{e} \\
\mathrm{Y}=6.476-0.169 \mathrm{X}_{1}+0.242 \mathrm{X}_{2}+0.32 \mathrm{X}_{3}-0.089 \mathrm{X}_{4}-0 . & \\
& 123 \mathrm{X}_{5}-0.371 \mathrm{X}_{6}-0.022
\end{aligned}
$$

The constant value of 6.476 showed that, if the value of age $\left(X_{1}\right)$, the intensity of UV radiation $\left(\mathrm{X}_{2}\right)$, UV exposure duration $\left(\mathrm{X}_{3}\right)$, knowledge of occupational health and safety $\left(x_{4}\right)$, the number of working days in a week $\left(\chi_{5}\right)$, and strong welding current $\left(x_{6}\right)$ had no change or fixed, the symptoms of photokeratoconjunctivitis will increase by 6.476. If one additional unit of age and the other variables is constant (fixed), the symptoms of photokertoconjunctivitis will increase by 0.169 .

Table 3 Pearson Corelation Test to Analyze Related Factors to Photokeratoconjunctivitis Symptomps of Informal Welding Operator in North Samarinda

\begin{tabular}{llccc}
\hline Dependent Variable & Independent Variable & $\begin{array}{c}\mathbf{p} \\
\text { (2-Tailed) }\end{array}$ & $\mathbf{n}$ & $\begin{array}{c}\text { Coefficient of } \\
\text { Correlation }\end{array}$ \\
\hline Symptom of & Age & 0.167 & 40 & 0.349 \\
photokeratoconjunctivitis & Intensity of UV radiation & 0.206 & 40 & 0.158 \\
& UV exposure duration & 0.056 & 40 & 0.849 \\
& Knowledge of OHS & 0.055 & 40 & 0.604 \\
& The number of working days & 0.001 & 40 & 0.157 \\
& Strong welding current & 0.085 & 40 & 0.206 \\
\hline
\end{tabular}


Table 4 The Results of Multiple Linear Regression Analysis

\begin{tabular}{llll}
\hline & Parameter & & Results \\
\hline $\begin{array}{l}\text { Correlation of coefficient } \\
\text { Coefficient of determination }\end{array}$ & & & $\mathrm{R}=0.455$ \\
$\begin{array}{l}\text { Simultaneous test (F test) } \\
\text { Partial test (t test) }\end{array}$ & & & $\begin{array}{l}\mathrm{R}^{2}=0.207 \\
\end{array}$ \\
& Constant & $\beta=6.476$ & $\mathrm{p}=1.096$ \\
& Age & $\beta=0.227$ \\
& Intensity of UV radiation & $\beta=0.242$ & $\mathrm{p}=0.349$ \\
& UV exposure duration & $\beta=0.32$ & $\mathrm{p}=0.158$ \\
& Knowledge of OHS & $\beta=-0.089$ & $\mathrm{p}=0.604$ \\
& The number of working days & $\beta=-0.123$ & $\mathrm{p}=0.037$ \\
& Strong welding current & $\beta=-0.226$ & $\mathrm{p}=0.206$ \\
\hline
\end{tabular}

\section{Discussion}

Results showed that prevalence of photokeratoconjunctivitis symptoms occurred in 50\% of informal welding operator in Samarinda. The results of this study are consistent with previous research by Sabitu et al. ${ }^{5}$ that concluded that some of the effects of welding on health include photokeratitis or arc eye. This results was in accordance with the opinion of Davies ${ }^{8}$ which concluded that welding emits a wide spectrum of radiations ranging between $200-1,400 \mathrm{~nm}$. These radiations include ultraviolet (UV) rays $(200-400 \mathrm{~nm})$. The visible light $(400-700 \mathrm{~nm})$ and infrared rays $(700-1,400 \mathrm{~nm})$. Ultraviolet radiation and far infrared (IR) are absorbed by the cornea and lens whereas visible light and near infra-red penetrate the retina. Acute exposure to UV radiation for instance, causes photokeratitis (commonly called as welder's flash eye or arc eye). Similarly Zamanian et al. ${ }^{9}$ conclude welding work has significantly increased the incidence of cataracts, keratoconjunctivitis, dermatitis and erythema in welders than in their nonwelders. In this study, the complaint on keratoconjunctivitis symptoms on informal welding operators are found similar with the results of Megbele et al..$^{10}$ such as eye strain, tearing, photophobia, blurred vision, and sensation of sand in the eye.

The study concluded that the informal welding operator in Samarinda that works using PPE is only $62.5 \%$. The use of PPE while working in this study is slightly lower than the use of PPE in textile workers in Bandung who accounted for $93 \% .^{11}$ The result is slightly better than the practice of the use of PPE in the operator welding in some other developing countries. For example in Nepal which concluded that only $47 \%$ of welding operators use personal protective equipment, ${ }^{12}$ in Kaduna Metropolis Northern Nigeria only $34.2 \%^{13}$ and in Benin City Nigeria only 35.9\%. ${ }^{6}$ The results of chi-square analysis concluded the use of personal protective equipments significantly associated with appearances of photokeratoconjunctivitis. These results are consistent with the finding of Alexander et al. ${ }^{14}$ that concluded morbidity of eye disorders, skin, and hearing loss in welding operators affected by the use of PPE's. To avoid photokeratoconjunctivitis, the informal weldings operator was advised to use PPE appropriatelly, in accordance with the American Welding Society ${ }^{15}$ stating the use of personal protective equipment (PPE) at all times is a good and safe practice by welders to protect from exposure to hazards and injuries during welding or cutting.

The results of this study are similar to results of previous studies which concluded that improper use of PPE has resulted in $87 \%$ incidence of photokeratoconjunctivitis. ${ }^{16}$ The use of personal protective equipment (PPE) at all times is a good and safe practice by welders to protect from exposure to hazards and injuries during welding or cutting. ${ }^{14}$

Job location not associated with prevalence of photokeratoconjunctivitis symptoms. The results of this study are not in accordance with statement of ICNIRP which concludes that outdoor workers receive significant exposure to solar UVR and are thereby at increased risk of suffering the adverse consequences associated with excessive UVR exposure of the eyes and skin. Reflection of solar UVR from the ground and work surfaces 
such as snow, sand and certain types of concrete and copper roofing plays an important role adding to the direct exposures. ${ }^{17}$ In this study, absence of relationship between work sites with photokeratoconjunctivitis were possible because only small proportion (10\%) work indoor, while the rest (90\%) work outdoor and experienced no photokeratoconjunctivitis.

The results show that most welding operators work outdoors (90\%), but cross tabulation results show that welding operators with photoceratoconjunctivitis are working indoors. Although the chi square test showed unrelated results, but this result can be said to be the same as Trissekti et al. ${ }^{18}$ research result which concludes parking attendants who work indoors have better lung function compared to parking attendants who work outdoors. These results are attributed to the lifestyle of the parking attendant (such as smoking habits, alcohol use and coffee drinking habits), smoking ban rules, good room ventilation and other environmental factors influences.

Results showed that the education level of welding operators were notassociated significantly with the prevalence of photokeratoconjunctivitis symptoms. The results do not support previous study that the level education of welding operator in Vellore India associated with an increased risk of eye injury. ${ }^{12}$ Age is not related to the appearance of photokeratoconjunctivitis symptoms. These results are similar to results of previous studies that concluded the age of welding operator not associated with cataract, in other words, age is not a risk factor for the occurrence of cataracts in welding operator. ${ }^{9}$ So we can conclude that age is not a risk factor for occurrences of many photokeratoconjunctivitis symptoms. The study do not support previous research by Kumar and Dharanipriya ${ }^{19}$ who concluded age, tobbaco use, alcohol use and institusional training are the predictor of injuries among welders in coastal south India.

We found the intensity of UV radiation and the strength of welding current is not related to the prevalence of photokeratoconjunctivitis symptoms. The results of this study contradicts to the opinion that expressed strong electrical currents affect the intensity of UV radiation, the greater the current strength is used, the greater the intensity of UV radiation. Strong currents more than 83 amperes harmful to the eyes and likely to cause photokeratoconjungtivitis. ${ }^{15}$ The absence of a strong relationship with the welding current photokeratoconjunctivitis in this study was understandable because only seven people are exposed to UV light with strong currents above 83 amperes.

The duration of UV rays exposure associated with the prevalence of photokeratoconjunctivitis symptoms. The study results were consistent with previous research that concluded duration of UV rays exposure related to photokeratoconjunctivitis. ${ }^{20}$ The research results are also supported by other research conclusions that stating the severity of the effects of UV rays exposure from the welding depends on several factors and one of them is a duration of exposure. ${ }^{21}$

The results of multiple linear regression analysis conclude that the most influential factor to the prevalence of photokeratoconjunctivitis symptoms on informal welding operrator in Samarinda is the duration of UV exposure. The results of this study is not equal to results of similar studies that concluded the most influenced variable to the incidence of photokeratitis on welding operator is the use of $\mathrm{PPE}^{22}$ and the results of other studies concluded strongest risk factors for cataracts in the welding operator is age and history of diabetes..$^{23}$ The implications of this research, local authorities are advised to increase attention to the informal welding operator in Samarinda by increasing knowledge of health and safety in welding activity, emphasizes the importance of using appropriate PPE and limiting the duration of exposure to UV radiation from the welding process (not allowed exposure to radiation UV exceed $0.1 \mathrm{~mW} / \mathrm{cm}^{2}$ for 30 seconds).

Determination of photokeratoconjunctivitis symptoms in this study were the limitations. It was determine using questionnaires (symptoms experienced told by respondents). It is advisable for further researches to do more comprehensive medical examination by medical personnel, to ensure the proper diagnoses.

\section{Conclusions}

In North Samarinda region, the symptoms of photokeratoconjunctivitis among informal welding operator were affected by duration of UV exposures, personal protective equipments used, health and safety at work knowledge and the number of working days. The most influential factor were the duration of ultraviolet exposures to the appearance of photokeratoconjunctivitis symptoms on informal welding operator. 


\section{Conflict of Interest}

The authors declare no conflict of interests.

\section{Acknowledgement}

We would like to thank to all of informal welding operator in north Samarinda village.

\section{References}

1. Asian Development Bank and BPS Statistics of Indonesia. The informal sector and informal employment in Indonesia. 2011 [accessed November 10, 2016]. Available from: www.adb.org/ sites/default/files/publication/28438/ informalsectorindonesia.pdf.

2. ILO Country Office for Indonesia and TimorLeste. Informal economy in Indonesia and Timor-Leste. 2016 [accessed November 10, 2016]. Available from: www.ilo.org/jakarta/ areasofwork/informaleconomy/langen/ index.htm.

3. International Commission on Non-Ionizing Radiation Protection in Collaboration with International Labour Organization and World Health Organization. Protecting workers from ultraviolet radiation. 2007 [accessed November 2, 2016]. Available from: www.who.int/uv/publications/Protecting_ Workers_UV_pub.pdf.

4. International Labor Organization. Occupational hazard datasheets [accessed October 10, 2016]. Available from: www.ilo. org/legacy/english/protection/safework/ cis/products/ hdo/htm/welder_arc.htm.

5. Sabitu K, Iliyasu Z, Dauda MM. Awareness of occupational hazards and utilization of safety measures among welders in Kaduna metropolis, Northern Nigeria. Ann Afr Med. 2009;1:46-51.

6. Voke J. Radiation effect on the eye-ocular effect of ultraviolet radiation. Optom Today 1999;8:30-5.

7. National Institute for Health Research and Development, Ministry of Health Republic of Indonesia. Basic Health Research 2013. Jakarta: Ministry of Health Republic of Indonesia; 2013.

8. Davies KG, Asana U, NKU CO, Osim, EE. Ocular effects of chronic exposure to welding light on Calabar welders. Niger J Physiol Sci.
2007; 22(1-2):55-8.

9. Zamanian Z, Mortazavi SM, Javad, Asmand E, Nikeghbal K. Assessment of health consequences of steel industry welders' occupational exposure to ultraviolet radiation. Int J Prevent Med. 2015;6:123.

10. Megbele Y, Lam KB, Sadhra S. Risks of cataract in Nigerian metal arc welders. Occup Med (Lond). 2012 Juli;62(5):331-6.

11. Respati T, Ibnusantoso G, Rachmawati M. Knowledge about byssinosis and the use of face-mask. GMHC. 2013;1(1):3-8.

12. Sundar BS, Singh SB, Sagtani RA, Raj Niraula S, Pokharel PK. Awareness of occupational hazards and use of safety measures among welders: a cross-sectional study from eastern Nepal. BMJ Open. 2014;4:e004646.

13. Sabitu K, Iliyasu Z, Dauda MM. Awareness of occupational hazards and utilization of safety measures among welders in Kaduna Metropolis, Northern Nigeria. Ann Afr Med. 2009;8:46-51.

14. Alexander V, Sindhu KN, Zechariah P, Resu AV, Nair SR, Kattula D, et al. Occupational safety measures and morbidity among welders in Vellore, Southern India. Int $\mathrm{J}$ Occup Environ Health. 2016 Oct;22(4):3006.

15. American Welding Society. Personal protective equipment (PPE) for welding and cutting. Safety and health fact sheet no. 33. May 2008 [accessed November 15, 2016]. Available from: http://www.aws.org/ technical/facts/FACT-33.pdf.

16. McIntosh SE, Guercio B, Tabin GC, Leemon D, Schimelpfenig T. Ultraviolet keratitis among mountainers and outdoor recreationalists. Wilderness Environ Med. 2011 Jun;22(2):144-7.

17. International Commission On Non-Ionizing Radiation Protection (ICNIRP). ICNIRP statement: on protection of workers against ultraviolet radiation. Health Physics. 2010;99(1):66-87.

18. Trissekti G, Kusmiati M, Budiman. The comparison of lung function between basement parking and street parking attendants in Bandung City. GMHC. 2014;2(2):66-72.

19. Kumar SG, Dharanipriya A. Prevalence and pattern of occupational injuries at workplace among welders in coastal south India. Indian J Occup Environ Med. 2014 Sep- 
Dec;18(3):135-9.

20. Majdi M, Milani BY, Movahedan A, Wasieleski L, Djalilian AR. The role of ultraviolet radiation in the ocular system of mammals. Photonics. 2014;1(4):347-68.

21. Canadian Center for Occupational Health and Safety (CCHOS). Radiation and the effects on eyes and skin. 2008 [accessed November 15, 2016] Available from : www.ccohs.ca/ oshanswers.

22. Muskita M, Martiana T, Soedirham O. Analysis of photokeratitis-related risk factors in welders of PT. PAL Indonesia (Persero) Surabaya. IJRET. 2015;4(4):512-6.

23. Slagor RM, La Cou M, Bonde JP. The risk of cataract in relation to metal arc welding. Scand J Work Environ Health. 2016 Sep;42(5):447-53. 